Originalveröffentlichung in: The 1848 Conflicts and their Significance in Swiss Historiography, in: Michael Butler/ 1 Malcolm Pender/Joy Charnley (Hg.), The Making of 1 Modern Switzerland, 1848-1998, London 2000, S. 3-34.

\title{
The 1848 Conflicts and their Significance in Swiss Historiography
}

Thomas Maissen

What does it take to make a revolution successful? How was it possible that, of all the countries concerned, Switzerland was the only one to see the success of its liberal and national movement in 1848 ? It was a success in a double sense: firstly, there was no political reaction and repression as elsewhere, the achievements of 1848 were not seriously threatened either by foreign powers or by internal opponents; and secondly, it was a lasting success, for from 1848 until today there has been constitutional and institutional continuity, making it possible to celebrate the 150th anniversary of modern Switzerland. Such continuity, which in addition has been peaceful, might not much impress a British audience that traces its national roots as far back as 1066, 1215 or even 1689 and 1707. But one has to compare modern Switzerland to the fate of the other continental countries: none of them has been spared territorial modifications or institutional and constitutional struggles throughout the last 150 years, and most have suffered enormously from these changes. Only the small Alpine republic has somehow muddled through the era of the nation state without too much harm. It has become more obvious over the last few years, however, that this success story has its dark spots, too, and it is high time for the Swiss to say goodbye to an unrealistically heroic view of their past. Nevertheless, they can be grateful for what happened in the 1840s, for a 'very civil war', as Joachim Remak has ambiguously called it, ${ }^{1}$ ended a lasting period of internal strife and insecurity and led to an institutional reconstruction 
of the old Confederation. Another outcome of that crisis was always possible: Switzerland could have broken apart in 1847 or the confrontation could have ended with a stalemate, leaving the federal state with its archaic structure. It is not the historian's job to discuss the 'what if' question, but it is not difficult to imagine what it could have meant to a traditional Switzerland of 22 sovereign, but tiny cantons to be confronted with the building of nations in the second half of the nineteenth century, especially the Italian Risorgimento and the German Reichsgründung.

\section{The conflicts leading to the new state of 1848}

To understand how close the decision of 1848 really was, we have to look first at the preceding critical years. ${ }^{2}$ The Swiss ancien régime fell in 1798, under simultaneous pressure from Napoleon's revolutionary troops and the claim for full citizenship and political participation widely diffused among subjects in the countryside and in the Gemeine Herrschaften, the areas dominated by several cantons conjointly. The product of this upheaval was the Helvetische Republik, a centralised state in line with the modern French rational model, which did not last. In 1803 Napoleon imposed a new constitution that again respected the rights of the sovereign cantons. Through the treaties of Vienna and Paris in 1815, Switzerland was granted eternal neutrality, and through the Bundesvertrag it again became the union of almost independent states it had been until 1798. The only national institution was the Diet (Tagsatzung), a congress of cantonal envoys who voted according to their government's instructions when they met in the Vorort, the capital which alternated every two years between Zurich, Berne and Lucerne. There was no centralised administration, and the competence of the Tagsatzung was limited to foreign and security policy. Thus it was quite deliberately that the name Bundesvertrag was chosen in 1815: this was no constitution among citizens, but a pact between confederate states. Yet it was this Bundesvertrag which contained the legal nucleus of the later conflicts. In paragraph 6, we read that the cantons were not to have separate alliances among each other which might be detrimental to the Confederation or to other cantons (keine dem allgemeinen Bund oder den Rechten anderer Kantone nachtheilige Verbindungen). On the other hand, according to paragraph 4 , each canton was entitled to ask other cantons for help if it was in danger. Finally, paragraph 12 contained a guarantee for the monasteries and their property.

The Bundesvertrag was barely contested until 1830 when once again, a French revolution brought about changes in many other European countries too. Already before Louis-Philippe's triumph in late summer, the Ticino had adopted a new, liberal constitution. Ten other cantons followed, yielding to the pressure of popular meetings in autumn and winter 1830; this was the case in Zurich, Berne, Lucerne, Solothurn, Fribourg, Schaffhausen, St Gallen, Aargau, Thurgau and Vaud. Here, modern liberal structures were founded: people's sovereignty within a representative democracy, separation of powers, personal and economic freedom. As there was political unrest in other cantons too, there were soon two opposing blocks within the Confederation which even formed alliances for some time: the conservative group (Sarner Bund) consisted of the founding cantons of Uri, Schwyz and Unterwalden, with Zug, Basle, Neuchâtel and the Valais, whereas the liberal Siebnerkonkordat brought together Zurich, Berne, Lucerne, Solothurn, St Gallen, Aargau and Thurgau. The strong opposition of traditional thinking, which was manifest also in liberal cantons, made the revision of the 1815 Bundesvertrag impossible although a new constitution, the so-called Bundesurkunde, was proposed in $1832 / 3$. Yet the revision failed not only because of the conservatives but also because on the other side the so-called radicals argued that the Bundesurkunde would not go far enough.

Thus, from 1833 onwards, we have three major political groups struggling for power within the cantons. We have to keep in mind that these were not the political parties we know nowadays but loose associations of men who shared political ideas. The differences between them were often subject to change and owed much to the particular situation in each canton and to other circumstances. Thus we must not be surprised that there are several famous cases of 'apostasy', liberals of the 1830 s who changed their ideas and became leading members of the conservative group. The most famous was the future leader of the Sonderbund, Constantin Siegwart-Müller. Bearing in mind the fluidity of the political boundaries, let us have a closer look at the three groups. ${ }^{3}$

Liberals: The Swiss liberal tradition was strongly influenced by Benjamin Constant's thinking insofar as it defended the goals of the French Revolution but, horrified by the Terreur, insisted firmly on 
the institutional means of avoiding its mistakes. For Constant, personal freedom and property went hand in hand; they allowed an individualistic elite to handle the commonwealth while the state did not intervene in their private affairs. The people was sovereign, but its representatives were almost fully independent of its will; as for the representatives, they were controlled by a constitution which could not be modified easily. Thus, the people's sovereignty found its expression and at the same time its limits in voting a constitution and electing the parliament, rights which were often restricted by census. Many liberals even went so far as to consider the parliament itself sovereign, once it had been elected on a constitutional basis; often, they considered the British parliament as their model. Still, it was the liberal intention to enlarge popular participation: in a fairly optimistic view of human beings, education was supposed to form good and skilful citizens who could acquire property, thus learn responsibility and fully participate in political power.

Radicals: Radicalism differed from liberalism mainly in its interpretation of people's sovereignty, whose exercise was seen as much less formal and clearly limiting the arbitrariness of its representatives. The radical tradition goes back to the Anglo-Saxon roots of John Wilkes who called for universal suffrage and also to Thomas Paine and Jeremy Bentham's egalitarian utilitarianism. But in Switzerland, the influence of Rousseau, of the French Jacobins and of German refugees, namely Ludwig Snell, was more important, as was the memory of the Swiss unitarian movement after 1798 and some Swiss political thinkers, Ignaz Paul Vital Troxler being the most important and most interesting. The unitarian theories produced centralised governments in some cantons, especially Vaud, and also claimed a strong central power for the whole nation. Such a government should also intervene, according to the radicals, in economic and social affairs, which liberals wished to keep free from interference from the state. The main distinction concerned sovereignty and the role of constitution and revolution. For liberals, a revolution was legitimate when it led to a constitution based on sovereignty of the people; but once a constitution was established, further evolution had to proceed within its settled rules. As the liberal Neue Zürcher Zeitung put it in 1846, the Constitution must restrain the people from becoming an absolutist ruler. ${ }^{4}$ On the other hand, Henri Druey, a radical leader and later member of the first national government, the
Bundesrat, stated in Rousseauian terms, that the supreme will of the people must not be bound by the Constitution which is a product of that will and not a contract. ${ }^{5}$ Thus the radicals could proclaim the people's right to revolution (Volksrecht auf Revolution) ${ }^{6}$ which was one of the dynamic elements in the crisis leading to the Sonderbund War.

Conservatives: The other dynamic element was situated, even if it sounds paradoxical, in the conservative camp. To understand this, we must differentiate further the varying components of that camp. What united them was their hostility towards the modernist elements which we find among radicals as well as among liberals: anticlericalism, secular education, rationalism, positivism, materialism, belief in progress. To all that, the conservatives opposed revelation and religious faith, the legacy of history and tradition, prescriptive law, old privileges and alliances, an organic view of the state and the Church linked to a metaphysical order. These convictions were shared by Catholic as well as by Protestant conservatives; the latter ruled in Basle, Neuchâtel and until 1846, Geneva, and always formed an influential opposition in the biggest liberal cantons of Zurich, Berne and Vaud. Yet the Protestant conservatives were eclipsed by the dynamics of the 1840 s caused by their Catholic counterparts. Here again we have to distinguish between the traditionalist particularists or (in the German sense of the word) 'federalists' on the one hand and the 'ultras' on the other. The particularists stuck to the century-old cantonal sovereignty and the solemn role of the Church in everyday life; they often belonged to the traditional patrician elites of the ancien régime and were, in the strict sense of the word, conservative insofar as they did not see why the Bundesvertrag of 1815 should be modified. Unlike the particularists, the 'ultras' thought that the struggle against liberal modernity must be fought with modern weapons: they relied on popular religious feelings, but also on the sovereignty of the people. Thus they fought the restricted circles of the ruling liberal elites, changed the Constitution with the help of popular movements, and introduced democratic instruments, especially the so-called 'veto', a predecessor of the referendum. The most famous leaders of the 'ultras' were the farmer Joseph Leu von Ebersol and the aforementioned Lucerne Schultheiss, the Mayor Constantin Siegwart-Müller. The latter was to be the 'spiritus rector' of the Sonderbund, and he even went so far as to develop a plan for changing 
the boundaries and governments in other Swiss cantons after a possible victory in a war. Such a revolutionary outcome would have guaranteed a stable equilibrium between Catholics and Protestants, between liberals and conservatives; it could never have been imagined by the traditionalist particularists who were so fond of the ancient laws which they wished to perpetuate among confederates.

Having sketched in these details about the main political groups, the early Socialist movement being of little importance in the Swiss context of 1848 , we can now give a brief overview of the confessional dynamics of the 1840 s that led to the Sonderbund War. We must recall that among the regenerated cantons of 1830 were Lucerne, Solothurn, Fribourg and the Ticino, all wholly Catholic, to whom we may add St Gallen and Aargau which both had a large Catholic population. With Protestant cantons like Basle, Neuchâtel and Geneva in the conservative camp, it was obvious to all contemporaries that there was a political, not a religious confrontation on a national level, which during the 1830 s remained unsettled. Yet, within the cantons, confrontations soon intensified over the closely connected issues of the Church and education. As early as 1834, seven liberal cantons tried to establish a Catholic national archbishopric under state control, but protests mainly in the Bernese Jura and diplomatic interventions by the Pope and France put a stop to that initiative. In 1839, the liberal government of Zurich appointed the rationalist theologian David Friedrich Strauss to its recently founded university; popular unrest, mainly in the countryside, opposed this Religionsgefahr, the threat to the Zwinglian orthodoxy. The government yielded and in the coup of September 1839 the conservatives took power. Throughout the country the impact was enormous: the conservatives adopted the techniques of popular assemblies and riots and Zurich, one of the three Vororte, highly industrialised and a flagship of the liberal movement, changed camps. What followed was a series of coups: the liberals won in the Ticino and they resisted conservative Catholic insurrections in Aargau and Solothurn. But after a first victory in 1839, they lost the Valais in 1844 following heavy casualties, whereas in Lucerne, another Vorort, a popular movement under the leadership of Joseph Leu von Ebersol ended in 1841 by peacefully establishing a conservative government.

Thus, around 1840 most cantons were touched by internal political unrest. The reaction of one of them, Aargau, raised the problem to a national level. In early 1841 , after the aforementioned insurrection, the radical government closed down the monasteries which were considered to be the nucleus of the armed revolt and this in spite of the fact that, as mentioned, the rights of the monasteries had been explicitly guaranteed in the 1815 Bundesvertrag. The Catholic cantons subsequently protested against this illegal act on the part of the Argovian government, but the liberal majority of the Tagsatzung declared in 1843 that it was satisfied with the reconstitution of the four Argovian nunneries. Even among conservative Protestants, notably in Zurich, few were prepared to defend the rights of the monks who since Zwingli had constantly been on the receiving end of criticism from the reformed Church. The conservative case became even more difficult among Protestants in 1844 when Lucerne appointed Jesuits to run its seminary. This symbol of the Counter-Reformation met with the traditional hatred of the Protestants and of many enlightened Catholics too. Here we can best see the difference between the conservative 'particularists' and the 'ultras': the cautious traditionalists opposed the appointment because they did not want to provoke religious unrest but the 'ultras' imposed it, as it enabled them to mobilise the flock of believers against radical aggression. Thus the confrontation became fiercer and fiercer as the extremes in both camps, 'ultras' and radicals, took over. In December 1844 a first armed attempt to overthrow the Lucerne government failed miserably. A second Freischarenzug with radical volunteers not only from Lucerne, but also from many surrounding cantons, was heavily defeated on 1 April 1845 when over 100 men lost their lives. As it was obvious that the liberal cantons had not prevented the attack from their territory and had even let the volunteers arm themselves in their arsenals, the scandal was tremendous at the Tagsatzung. The fury of the Catholic conservatives grew even further in the summer of 1845 when Robert Steiger, a Lucernese radical leader of the second Freischarenzug, who had been sentenced to death, managed to escape from prison and was welcomed as a hero in the liberal cantons. A month later, a former guerrilla assassinated Joseph Leu von Ebersol while he was asleep.

Thus, in 1845, there was little space left between those who wanted to fight the radical aggression against Christianity and law and those who thought they were opposing the ultramontane reaction against modernity and individual rights. The once large juste milieu that ran 
from moderate conservatism to moderate liberalism, had to choose. It was not by chance that immediately after the second Freischarenzug, the liberal Jonas Furrer was elected burgomaster of Zurich - the conservative regime, considered a tool of the Jesuits, was abolished. Similarly, in Vaud the liberal government was overthrown by a radical revolution because the population did not agree with its moderate position towards the Jesuits. As a result of the second Freischarenzug and the ambivalent role of the Bernese government, the radicals gained power in that canton, too: Ulrich Ochsenbein, a leader of the volunteers, became a member and later Schultheiss, mayor of the government. In that role, at the head of a Vorort, he was to become president of the Tagsatzung in 1847.

At this point, we have to look at the institutional conflict. Since the failed revision of $1832 / 3$, Switzerland had been split between the particularist federalists and the partisans of a strong, modern nation state. Often enough, the obvious lack of efficiency of the Tagsatzung had been the subject of complaint; often enough, pressure from surrounding monarchies like France and Austria had shown that the Confederation could not match the power of centralised states. In addition, since 1839 the Tagsatzung had been watching the series of coups without intervening to settle them; on the contrary, Lucerne as a Vorort in 1844 played a major part in worsening the crisis in the Valais. But it was not enough that Switzerland lacked an executive that could impose law and order; there was not even a legal procedure in sight which could furnish it. The 1815 Bundesvertrag did not contain a single paragraph about its revision, as it was meant to be eternal. Already in $1832 / 3$ the conservative cantons declared that they considered the Confederation a pact between independent cantons that could only be revised if all of them agreed. How could things continue as they were in the mid-1840s, once feelings among confederates had become much more bitter than they were a dozen years earlier?

What became the final step towards disunion paradoxically ended up resolving the constitutional and institutional problems. On 11 December 1845 Uri, Schwyz, Unterwalden, Lucerne, Zug, Fribourg and the Valais formed a defensive alliance, labelled the Sonderbund (separatist league) by its antagonists as soon as they found out about it. The seven cantons, all of them wholly Catholic, justified their alliance by referring to the guerrilla attacks which the Tagsatzung had not prevented. But this time, unlike the formally correct appointment of the Jesuits, the conservatives had chosen an illegal way themselves: the aforementioned paragraph 6 of the 1815 Bundesvertrag stated that separate alliances which might be detrimental to the Confederation or other cantons were forbidden. This danger could not be denied: the surrounding conservative monarchies, especially Guizot's France and Metternich's Austria, were interested in a weak and conservative Switzerland and did not hide their sympathy for the Sonderbund. The future of the Confederation was at stake: it was possible that the conservative cantons might form a separate union or change the existing one, as we have seen with Siegwart-Müller's project.

The new threat definitely clarified the situation. At the Tagsatzung of August 1846, only ten cantons voted for abolishing the Sonderbund. Five cantons were still neutral but after a short civil war, the radicals gained control of Geneva, and there was only one vote missing for a majority of 12 votes among the 22 cantons. The Catholic Appenzell-Innerrhoden would not furnish it, nor would Neuchâtel, which still had the King of Prussia as its sovereign. That left Basle, where a peaceful revision of the Constitution did not convulse the conservative government, or Fribourg, where the radicals attempted a coup in early 1847 in order to leave the Sonderbund, but were easily defeated. In the elections of May 1847 St Gallen decided for Switzerland. Until then, conservatives and liberals had had exactly the same number of seats in that canton, and thus St Gallen had not yet chosen its camp. Once a small, Catholic constituency unexpectedly voted liberal, there was a majority of two seats and St Gallen joined the majority at the Tagsatzung. This case shows how very close the decision was, not only in St Gallen, but all over Switzerland. It even seems that one small village in that constituency, Amden, was decisive for the whole country because, as a form of protest, the inhabitants voted against their own - conservative - magistrate.

This leads us, after the political, the confessional and the institutional, to the economic conflict, the fourth one leading up to 1848 . The magistrate of that small village of Amden was accused, immediately before the vote, of having speculated on flour while the villagers were starving. Since 1845, Switzerland had been suffering from potato rot and famine, the same one that caused catastrophe in Ireland. The Swiss situation was not as disastrous, but it was difficult 
enough and contributed to radicalising the two camps which accused each other of worsening the situation. In this period of early industrialisation, there were also other reasons for existential insecurity and even violent protest: in 1832, the rural town of Uster near Zurich experienced a riot of weavers and domestic labourers who destroyed the newly installed mechanical looms and finally burnt down the whole factory. Thus, the manufacturers, who formed an important group among the new liberal elites, were soon confronted with serious unrest among the less privileged who in 1830, had helped them to get rid of the old patrician rulers. It was again no coincidence that the imprisoned rioters of 1832 were freed in 1839 , after the conservative coup against the liberal regime - the country dwellers often combined religious and economic feelings against the new elites. Let us mention a final economic problem, the unification of a national market. Already the Bundesurkunde of $1832 / 3$ had proposed a federal monopoly on customs, on the post, on coinage and measures, but this attempted revision failed and traditional particularism continued. Protectionism on the part of the cantons thus opposed the liberty to carry out a trade and they defended their own citizens and their products while being unable to defend common Swiss interests against the bigger surrounding powers. The Tagsatzung and non-governmental institutions, such as the Schweizerische Gewerbeverein, founded in 1843, tried to find solutions within the old system, but they did not agree about the procedures and failed. Among other effects, this meant a notable delay in railway-building. By 1848 a single line, from Strasbourg, had barely touched Swiss soil at Basle and the cities of Zurich and Baden had just been connected by about 20 kilometres of track. There were plenty of other initiatives, but they were as yet unable to overcome cantonal selfishness.

In connection with the economic problems we must look at social change due to industrialisation and the new, liberal public space. On one side of society, we have a growing group of dependent workers and petty peasants with very limited financial means - in these difficult times, many of them were ready for visions, be it the religious faith of the ancestors or the liberal prediction of eternal progress. Metternich himself judged the riots and the radical triumph in Geneva as the first successful Socialist revolution on the continent. But in the end, even the radicals in Switzerland turned out to be rather moderate and often even quite elitist. Rather than a social movement on the part of the lower classes, the Swiss regeneration involved changing those in power: the old urban patricians who were at the head of the cantons until 1830 yielded their place to the bourgeois des talents, the liberal professions, the civil servants, and the entrepreneurs who most often originated in the many municipalities to whom full civil rights were given only after 1798 . This rapid and often radicalising exchange of elites can best be seen in Berne, which went from the old aristocrat Rudolf von Wattenwyl, mayor in 1830, to the moderate regime of the liberal Schnell family from the municipality of Burgdorf, who had to hand over power to the radical Charles Neuhaus in 1839; in his turn, after the catastrophe of the Freischarenzüge, Neuhaus yielded to the even more radical group surrounding the lawyers Ochsenbein and Jakob Stämpfli, born into a modest farming family only 26 years earlier. Thus the experience that the revolution maybe does not eat but overthrows its own children is endemic in these years in the usually tranquil Swiss cantons.

We have looked at the political, the religious, the institutional, the economic and the social aspects of this unrest which characterises the regeneration, especially during the years after 1839. Yet we must state that contemporaries mostly experienced the events leading to the new state of 1848 as a political crisis: one coup followed another, almost every canton had its successful and failed upheavals, and the Tagsatzung was for a long time unable to intervene and procure peace among the different factions. The longer it went on the more even moderate people agreed that there could only be Alexander's solution for the Gordian knot in Swiss policy. In the summer of 1847 finally, one group, the liberal one, had the power and the united force to impose solutions in the controversial matters: the 12 cantons decided to dissolve the Sonderbund, to expel the Jesuits and to revise the Constitution. The legal foundation for the last two decrees was thin: the Jesuit question belonged to the jurisdiction of the canton concerned and as mentioned, the 1815 Bundesvertrag did not provide for a revision through majority decision. The Sonderbund therefore opposed the edicts and mobilised under the leadership of Ulrich von Salis, a Protestant conservative. Ironically, another Protestant conservative, Guillaume Henri Dufour from Geneva, was named General of the Tagsatzung troops, which turned out to be the better choice: after a short campaign of about 20 days with roughly 100 casualties the Sonderbund surrendered. 
The cases of Dufour and von Salis show once again that this was a political, rather than a religious conflict, and that the decisive political contest for the extremes was to convince the hesitating juste milieu. With their patriotic reference to the Swiss nation, the radicals succeeded far better. Besides the political conflict of course, the confessional animosities did a lot to mobilise the ordinary soldiers on both sides, but they were not at the origin of the war. What was at stake can best be seen in the words of two leading Lucerne politicians: the liberal Kasimir Pfyffer did not join the Sonderbund troops because, as he put it, 'every Swiss should first consider himself a confederate and only after that the citizen of a canton'. ${ }^{7}$ On the other hand, the conservative Philipp Anton von Segesser wrote immediately after the lost war: 'To me, Switzerland is only of interest because Lucerne - which is my country (Vaterland) - lies in it. If this canton no longer exists as a free, sovereign part of the Confederation, I care as much for the latter as for Tartary. ${ }^{8}$ Modern nation state or traditional confederation, that was the question in 1847 and 1848 . Of course, both sides called it a fight for freedom and democracy, but judged from today, we clearly see on both sides the shortcomings of this rhetoric. Out of fear of direct - and conservative - democracy, the victorious liberals abolished in Zug and Schwyz the Landsgemeinde and in Lucerne the 'veto', a kind of referendum. In addition, without the military threat from the neighbouring cantons and many legalistic tricks, the new radical regime in Fribourg would have given way much earlier than 1856.

Still, these problematic aspects were eclipsed by the success of the new Constitution, quickly designed in February and March 1848, discussed in the parliaments of the cantons and at the Tagsatzung, accepted in a referendum by a big majority of voters and 15 and a half cantons, and proclaimed on 12 September 1848 . As it is impossible to go into too much detail here, I will just mention the most important aspects: a national executive, the federal council; a bicameral parliament according to the American system, thus guaranteeing considerable influence to the small cantons; several freedom rights, such as - to some extent - universal suffrage for men and freedom of settlement; unification of customs, post, coinage, measures and weights; further unification in military issues; federal competence to promote the commonwealth, through public enterprises or a national university. It is clear that even besides the obvious model of the USA, many foreign ideas influenced the Constitution of 1848. Yet, it was declared a 'home-grown' Swiss creation from the beginning to avoid the hated memory of the Helvetic Republic of 1798.

Let us now return to the initial question: what did it take to make the Swiss revolution of 1848 successful? Maybe first of all the fact that it was not a real revolution or at least managed fairly well to hide its revolutionary aspects. The Tagsatzung was the only national authority and it was the Tagsatzung that suppressed the rebellion of the Sonderbund; as the war was quickly won, there was no period of anarchy during which foreign powers could have intervened under some pretext. Once the military solution had been imposed, there remained no serious internal opposition either; Protestant and Catholic conservatives surrendered and accepted the new Constitution, and those who did not, did not resist openly but went on hoping for help from abroad. But that became impossible for several months after February 1848, when first France, then Austria, Prussia, and almost all German states had plenty to do themselves with their own domestic revolutions. The Tagsatzung used precisely this period without external threat for writing and voting the new Constitution that went much further than one would have expected in late 1847 . Yet, the fathers of the Constitution could refer to the failed Bundesurkunde of 1832 and - maybe even more important - to almost 20 years of modern parliamentarianism and constitutionalism on a cantonal level. The revolution had actually been going on since 1830, and even though many of the fathers of modern Switzerland were surprisingly young, they all had considerable experience in handling political crisis. This led them finally to remain neutral and stay outside the European struggles of 1848 and 1849 , although there was a great deal of pressure, even within the government itself, to join the liberal camp in the general 'fight for principles'. This decision, which maybe saved the country from a military intervention after the victory of reaction all over Europe, was taken according to the Swiss state's raison d'état; but it also reflected two essential differences from the revolutionary movements abroad. In 1847 and 1848, there was neither a social nor a national question in Switzerland. While France installed a new Napoleon to save the country from class war, the Swiss workers and peasants were still far from developing classconsciousness; their identity was confessional or political, cantonal or 
national, but barely social. On the other hand, a quite homogeneous, national bourgeoisie des talents was already formed and ready to take power and responsibilities, but also to co-opt new members from the lower classes to whom they suggested education as the means of social ascent. While social conflicts were still to come, the national frontiers had already been clarified for some time. In the critical years from 1798 to 1815 , Switzerland had found its territorial form which was not seriously questioned afterwards; if the Swiss did not agree about the future institutions of their country, that did not mean that they wanted to split it up or join another state. Through newspapers, the army, clubs and societies, there had been, since 1815 , an ever-extending national public domain. Characteristically, there were French- and German-speaking cantons in both camps of the Sonderbund War and the boundary between the moderate eastern liberals and the interventionist western radicals was not the famous Röstigraben, but somewhere between Berne and Zurich. Thus the Swiss Confederation somehow succeeded in bringing a pre-national, political, republican identity into the era of the democratic national state. It has lasted since then, thanks to integrating myths and thanks to a constitution which allows continuous adaptation to a world that is changing faster and faster.

\section{Swiss historiography about the Sonderbund and the new Confederation}

The second part of this essay deals with the aftermath of 1847 and 1848 in Swiss historiography. Of course, many contemporaries wrote their memoirs or impressions and thus forged the ideas of their successors. ${ }^{9}$ The leader of the Sonderbund, Siegwart-Müller, published his account in 1866 and the title - 'The victory of violence over law' - says almost everything. It is an apologia for the Sonderbund which, as Siegwart admits, was by then often criticised even among those who were once its members. Siegwart goes on to proclaim that 'centralisation' is the 'murderer of people's freedom' and the separation of state and Church leads to the decline of virtue and Christendom. ${ }^{10}$ Siegwart's former secretary, Joseph Balthasar Ulrich, also chooses a significant title in order to contradict liberal terminology. The Sonderbund War was known as a Bundesexekution, the execution of a federal decision against rebels, whereas Ulrich, who himself served in the war, entitles his book Bürgerkrieg in der Schweiz: a civil war against the acknowledged legal maxims and clear rules of the Confederation (anerkannte Rechtsgrundsätze und klare Bundesbestimmungen). Balthasar, who finished his book in 1850 , sees the tragedy of ancient, original, Catholic Switzerland as a prelude to the fight for principles in the whole of Europe, the revolutions as an effect of planned conspiracy. Yet he hopes that the new Confederacy in spite of its unitarian and factious character can be 'a rampart against injustice and arbitrariness, a rampart for the freedom of confessions and Christian life, a bond of reconciliation and union of the people and a bulwark for an independent country'. ${ }^{11}$ Here we see the readiness of many of the vanquished to participate faute de mieux in the new state; even Bernhard Meyer, Siegwart's co-leader in the Sonderbund and later exiled in Munich, summons his partisans in summer 1848 to vote for the new Constitution, because a refusal would either continue the chaos of illegality or provoke a real unitarian constitution that would finally smash the rights of the cantons. ${ }^{12}$

The most interesting conservative voice is perhaps that of Gallus Jakob Baumgartner, an 'apostate' like Siegwart-Müller. In 1832, Baumgartner edited the liberal Bundesurkunde, but as a Catholic he switched camps around 1840 . Consequently he is very critical of the radical 'tyranny' and the illegal measures that led to the new Constitution, but he welcomes the Constitution itself which could promote internal welfare and avoid disunion against foreign parts. Baumgartner is convinced that an evolution of the particularist Confederation was inevitable and cannot be revoked, but at the same time, he calls for republican virtues and simplicity to counterbalance the dangerous, corruptive influence of foreign courts and modern, mob-led politics. ${ }^{13}$ In an accurate analysis of the new Constitution, Baumgartner states in 1851 that it gave the federal institutions the maximum power that Swiss tradition could admit; yet, the real danger was not centralisation but the fact that the ruling liberals illegally abused their powers, and that the big cantons, the winners of the war, flouted the national institutions they themselves installed while the losers lacked the strength for such a policy. ${ }^{14}$

Similar in some ways to Baumgartner, the moderate liberal Niklaus Friedrich von Tschudi, also from St Gallen, keeps his distance from the factious extremes in both camps: the radicals have been acting illegally, but the Sonderbund has willingly risked an intervention of 
foreign powers. Thus its dissolution has become inevitable and corresponds to the nation's needs, interests and laws. ${ }^{15}$

The winners, like the radical Jakob Amiet from Solothurn, celebrate a victory of the 'nation against foreign, non-Swiss, completely nonnational elements', that is the aristocracy, Rome and the Jesuits. Like many losers, liberals consider Swiss events a prelude to the uprising of peoples all over Europe, but unlike their adversaries, they see this as a positive step towards universal progress. ${ }^{16}$ The Argovian J. Martin Rudolf describes the struggle against fanaticism, superstition and intolerance which led the innocent Catholic people to fight a hopeless war against their confederates. To him, the Swiss troops of his time are no longer in the mercenary tradition of the ancien régime, but have rediscovered the roots of their heroic ancestors like Winkelried and the warriors of St Jakob. ${ }^{17}$ This is the path the liberal and national interpretation of the critical years had already established earlier ${ }^{18}$ and one which was to develop further in the nineteenth century: while the original cantons semi-consciously continue the decadence and dependence of the ancien régime, ${ }^{19}$ the liberal fighters for freedom are the true heirs of William Tell and the original struggle for independence and democracy.

Another lasting feature that made the Swiss revolution acceptable to many hesitating members of the juste milieu like the Bernese aristocrat Anton von Tillier ${ }^{20}$ was the fame of Guillaume Henri Dufour. With his memoirs, which he wanted to be published only after his death, the general himself contributed to his lasting image as a chivalrous, moderate and modest soldier who did his duty and yet overcame the bad feelings of his enemies. ${ }^{21}$ Even today Dufour remains, along with Tell, Niklaus von Flüe, Henri Dunant and Henri Guisan, one of the most popular historical heroes of Switzerland; many roads bear his name, as does the Dufourspitze, the only mountain in the Alps to be named after a real person. Dufour somehow symbolises the historical necessity of the Sonderbund War and the subsequent foundation of the new Confederation: a conservative himself, he obeyed the call of the nation and through his clemency integrated the vanquished into the new state. Although in reality many Catholics had a long way to go before accepting the federal state, the memory of Dufour could help them.

After all, they had to adopt the view of their enemies, as liberal historiography was to dominate for almost a century. The German refugee
Peter Feddersen, who witnessed the crisis already in Basle where he was naturalised, finished in 1866 a History of the Regeneration, describing it as an independent republican movement, 'without any foreign interference', heading towards a new order which reflected the growing national consciousness. Even if - according to Feddersen - liberal postulates like legal equality, religious freedom, unified law or freedom of trade were not fully imposed against particularist opposition, the reborn, powerful Confederation could set about many new tasks and reached a level from where further natural development became easy. ${ }^{22}$ The major syntheses of the following decade mostly follow the same interpretation: the liberal movement is natural, some overreactions from the radicals, like the Freischarenzüge, deplorable, but the real and stubbornly defended crimes are the appointment of the Jesuits and the creation of the Sonderbund. A truly harmonious national policy wins with Dufour in an inevitable war and frees Switzerland from internal unrest and external influence: the wise masterpiece of a new constitution, beyond particularism and unitarianism, moderate even towards the losers and in full harmony with the Swiss federalist tradition, becomes, together with neutrality during the 1848 revolutions, the basis for further peaceful and organic prosperity. We can read this version in Karl Dändliker's national history of 1887 , leading us from the conservative tyranny in Lucerne to the Constitution which finally strengthens national feelings and national power. ${ }^{23}$ Similarly, Johannes Dierauer, in his fundamental History of the Swiss Confederation, opposes (and thus justifies) the patriotism of the Freischaren to the 'formal order of state' that clearly objects to their deeds; the Sonderbund crisis is an 'inescapable natural force', and the new Confederacy turns out to be an equally natural result of the 'indigenous old historical tradition and an ever-growing internal stimulus'. ${ }^{24}$ Numa Droz, a former federal councillor, praises in his popular description of the regeneration the 'warm rays of the confederate spirit' of $1848 .{ }^{25}$ In 1902 , Theodor Curti, like Droz a former journalist and politician, publishes a chapbook about his country in the nineteenth century, telling, without disdain for the conservatives, an elementary drama about the bold liberals fulfilling the 'dream of a whole generation'. ${ }^{26}$ Max Huber, in the midst of the First World War, calls the Constitution the 'most fortunate and important act in Swiss history'. ${ }^{27}$ The interpretation of 1848 as a somehow transcendental stroke of luck can be read in many later texts, too. ${ }^{28}$ 
The loser's voice is not completely missing, as we have for example Joseph Hürbin from Lucerne, who blames the leaders of the Sonderbund for its defeat while the people were prepared to sacrifice themselves. ${ }^{29}$ But Hürbin, who in 1903 was still complaining about the unitarian elements of the 1848 Constitution, is an exception. The liberal interpretation prevails, even if or rather because it points out what a decisive break the years between 1798 and 1848 really were: continuity, not revolution is the motto. In 1891, the Swiss national state invents and celebrates for the first time the tradition of the 1291 oath on the Rütli; ${ }^{30}$ it is symptomatic that in the same year, the first member of the Catholic conservative party joins the Federal Council. In these years when the coalition of the non-Socialist parties, that is the different liberal groups, the conservative losers of 1848 and the farmers is formed, early history definitely becomes the focus of Swiss identity while the conflicts leading to 1848 are eclipsed. ${ }^{31}$ Thus in 1898, there is no national jubilee; only Berne celebrates the memory because it is linked to its election as federal capital. ${ }^{32}$

A sober approach is also typical of mere historians of the Constitution: Carl Hilty, in 1891, sees the work of 1848 as nothing but the implementation of the Bundesurkunde of 1832 and a first step towards the revised Constitution of 1874 which installed truly democratic instruments like the referendum. ${ }^{33}$ Similarly, Eduard His points out the continuities in constitutional thought and the decisive role of the democratic movement leading to the revision of $1874 .^{34}$ Andreas Heusler, in 1920 , does not go that far and speaks of the 'fundamental upheaval' of 1848 , but still points out the many compromises in the new Constitution. ${ }^{35}$

In the first half of the twentieth century, the liberal interpretation acquires a new element. In the first edition of his Swiss History, published in 1920, Ernst Gagliardi from Zurich, a leading historian of his time, poetically praises the liberal triumph as Switzerland's 're-emergence among the truly independent states' and her regaining 'civilising equality' with other nations, even a fulfilment of Zwingli's programme, because Catholicism and especially ultramontanism are definitively rolled back. ${ }^{36}$ Yet in 1937, when Gagliardi rewrites his text, he insists on the economic situation which imposes political modernisation against traditional particularism. ${ }^{37}$ What has happened? The rapid economic development of the nineteenth century had often been described, but never in relation to $1848 .{ }^{38}$ However, in
1912 the later famous economist and diplomat William Rappard, then a student at Harvard, first reflects on the 'economic factor in the generation of modern Swiss democracy'. ${ }^{39}$ In 1928, the year of his death, Eduard Fueter publishes a history of Switzerland since 1848 , with a first chapter describing the economic structures in the middle of the century. Before going on to discuss the political institutions of the highly praised Constitution, he deliberately first presents the 'new creations concerning commerce and economy'.40 Gagliardi's changed view is obviously due to Fueter, and another admirer of Fueter's, Hans Nabholz, writes in 1944 a fundamental article about 'the rise of the federal state from the perspective of economic history', where he puts forward the view that the adaptation to economic change was the 'first and continually effective stimulus for constitutional reform' but admits that only the political struggle finally led to it. ${ }^{41}$ Analysing discussions about customs duty, Walther Rupli in 1949 concludes that the economic and political motives leading to the new state carried equal weight. ${ }^{42}$

After Nabholz, the economic aspects of 1848 are stressed in many other books ${ }^{43}$ and the rise of National Socialism and endemic antiparliamentarianism in Switzerland also gives another impulse to national historiography. In 1938, Werner Näf states that Switzerland was the first European state to become a democratic republic as a result of the country's past and characteristics; here, 'the individualistic revolution was a revival, not a rupture'. ${ }^{44}$

The experience of the Second World War strengthens not only the democratic identity, but sharpens sensitivity for the victims and tensions of 1848 . The direct line, be it political or economic, that earlier historiography drew from the Enlightenment to the liberal apotheosis of 1848 and that has, in 1948, one of its last heralds in Gottfried Guggenbühl, ${ }^{45}$ is openly questioned by Edgar Bonjour after the war, although in an earlier synthesis he himself gave quite a traditional, rather undifferentiated picture. ${ }^{46}$ In 1948 , Bonjour stresses the divergence of interests and points out that in such a complex situation, many alternative solutions remained possible. Thus the new Constitution is no longer a child of the liberal Weltgeist, but a stroke of luck followed by national reconciliation. ${ }^{47}$ Bonjour sees the Bruderkrieg as a catastrophe, but praises the moderation of the victors; still, his real sympathy lies with the conservative mediators of Basle, the 'voice of conscience' among the factiousness, to whom Bonjour dedicates 
a specific piece of research. ${ }^{48}$ This distance from the liberal tradition is partly explained by the national union during the Second World War that left little place for century-old antagonisms and little respect for civil wars; on the other hand, the warnings of such brilliant conservatives as Jacob Burckhardt became horribly true: the sovereign people, so cherished by the radicals, democratically elected Hitler in Germany and turned into a mass and a populace under his rule.

These new aspects of 1848 were canonised in 1948 with the official book of the jubilee, a vade-mecum for every interested citizen entitled Swiss Democracy 1848 to 1948 , with Ferdinand Hodler's Tell on the frontispiece and an introduction by Enrico Celio, the President of the Federal Council. Celio compares the Constitution of 1848 to those of 1798,1803 and 1815 and insists from the beginning that it is the only one which is completely Swiss in origin and content. Celio, a member of the Catholic conservative party, does not mention the Sonderbund War, but speaks of 1848 as a reform which set the country free from humiliating foreign influence. 'Be and remain true to your character' is the exhortation of the highest representative of Switzerland; be faithful to republican freedom, Swiss democracy, independence and neutrality which all are older than the liberal revolutions of the past two centuries. If we can believe E. Abderhalden in the same book, the new Constitution even 'corresponds in all decisive regulations to the nature and the needs of the people and the cantons and is a true masterpiece of political insight'. With Celio's and Abderhalden's words, the Constitution becomes the natural link between the glorious past of all Swiss and modern democracy as the result of a virtuous and harmonious people - it is a typical milestone of the Swiss Sonderfall which has nothing comparable in the universe. ${ }^{49}$ This is a view which is shared by other important members of Celio's conservative party; the losers of 1848 have accepted that the 'transition from the federal union to the federal state was necessary to preserve the country'. ${ }^{50}$

Among the semi-official celebrators of the jubilee in 1948, we find three authors we have already mentioned: Nabholz, Huber and Rappard. Unlike the harmonious politicians, Hans Nabholz chooses strong words: a fight between ideologies (Weltanschauung) led to a revolution, and the new Constitution forged national consciousness. ${ }^{51}$ Nabholz shares the pride that the democratic constitutional state of 1848 resisted the dictatorships in neighbouring countries with Max Huber who, at the official celebration in Zurich, praises 1848 as an expression of the century-old Swiss thirst for freedom. Yet, according to Huber, this freedom must constantly be asserted and defended, in 1848 as in his own dangerous times. In the age of totalitarianism, Huber sees the liberal Constitution as a means of defending individual freedom against the overwhelming state: through participation, guaranteed personal rights, checks and balances, the federative structure of the state. ${ }^{52}$ William Rappard also thinks gratefully that the 'natural solution' of 1848 not only corresponds to the necessities of that critical time but also to the needs of later generations and even to the eternal requirements of the Swiss people which somehow has itself given birth to the Constitution in its 'truly Swiss spirit'. ${ }^{53}$

Among the leading Swiss intellectuals who raised their voices in 1948, Karl Schmid, Professor of German literature at the Federal Institute of Technology (ETH), was pensive rather than emotional. He argued that it was nothing short of a miracle that the state established in 1848 had lasted 100 years. He warns those who like to talk about 'our' achievements as if those of their ancestors were their own deeds. Have the Swiss been faithful to the Constitution of 1848 ? According to Schmid, the central state has grown in an unliberal, 'socialist' direction, reducing individual freedom, yet it attempts to protect the petty people of the lower classes and the whole nation itself in its fight against totalitarian states abroad. Would the liberals of 1848 agree with the foreign policy of their successors which is entrenched resistance rather than devoted sacrifice? What they understood by neutrality was prudence and readiness, willingness to fight with arms if necessary, and they would agree with that part of modern Swiss politics, but they would be suspicious about its material gains and not forget its moral aspects. ${ }^{54}$

Corresponding to the national union during and after the war which included the Socialists in fighting off the Nazi and Communist threats, the moderate left also participated in all these celebrations. Yet there were symptomatic intellectual and journalistic polemics about the meaning of 1848: while Socialists often claim to be the true heirs of the (radical) movement of the 1840s, the Freisinn angrily counters that there has been liberal continuity within its own party for at least the last 120 years. This position can imply criticism against Fueter's and others' materialist interpretation of 1848 , which is still considered to be the idealistic child of liberal convictions. The ideological background at the beginning of the Cold War is even 
more obvious in another respect: for the liberals, 1848 means the definite end of a revolutionary era, because a fair constitution was established; on the other hand, the Socialists interpret 1848 as a revolution which does not necessarily have to be the last one. ${ }^{55}$ This view goes back to Robert Grimm, one of the eminent leaders of the party, who, imprisoned as a leader during the general strike of 1918 , wrote his History of Switzerland in its Class Conflicts, following the tradition of historical materialism. He explains the formation of the federal state as the 'bourgeois revolution' against aristocracy, a conflict that could only be resolved through 'raw violence', which in Grimm's own days became so frightening for the bourgeois. The defeated guerrillas of 1845 changed their methods and started a legalised revolution' with the strength of a national army, by which means they brought to an end their struggle of 50 years for a modern state and a unified economic area. Grimm praises the courage and the initiative of the former radicals, so different - according to him - from his contemporaries. Yet their Constitution was coined by the conservatism of the petty bourgeoisie that dominated the social structure of the country. Now that this structure has changed so much, the future will belong to the working class and international revolution. ${ }^{56}$

In his later political life Grimm was to moderate his prophecies, but the Socialists' claim for the heritage of 1848 endured, as is demonstrated by writers like Max Frisch and Peter Bichsel. Bichsel thanks the liberals to whom he believes he owes his personal freedom much more than to William Tell: 'they wanted to impose the idea of a state, not only economic interests'. The Constitution of 1848 was the work of the opposition, of the left, which, according to Bichsel, is one reason why their liberal 'successors' prefer the memory of 1291 to that of $1848 .^{57}$ In Frisch's Stiller (1954), the protagonist White/ Stiller regrets that the conservative and indolent Swiss do not want their future, but their past. The last time they had a real project, a real aim must have been around 1848: a great, truly lively and creative epoch. In achtung: Die Schweiz, published around the same time (1955), Frisch, together with Lucius Burckhardt and Markus Kutter, again demands that Switzerland should have a goal and proposes a 'new town': such a design for the future is worthy of the memory of 1848 , where political parties made a Utopia become reality. ${ }^{58}$

Such judgements went on haunting the political foes who are described as mere executors of the liberal revolution and marked their interpretation of the nineteenth century, too. The antagonists of 1848 , conservatives and liberals, have already come together since at least 1891 in their anti-Socialism which - in spite of some sympathies, even in bourgeois circles, for the USSR which defeated Hitler's troops - dominated Switzerland again after 1948. It is quite symbolic that in a very popular, illustrated history of Switzerland, published several times from 1961 onwards, the modern period is covered by a Catholic from St Gallen who taught in the quite orthodox college of Schwyz. Emil Spiess wrote impressive studies on the two fascinating authors I. P. V. Troxler and G. J. Baumgartner, both torn between Catholic faith and liberal convictions. Spiess not only shows much sympathy for the legal position of the losers of 1847 ; in the middle of the Cold War, he sees a decisive role for German emigrants and Communists for the radical cause in the Sonderbund crisis and cites extensively Friedrich Engels's article 'The Swiss Civil War' published on 14 November 1847. What Spiess declares to be an impartial position has become even more than in Bonjour's case very close to the liberal-conservative juste milieu which Spiess still criticises for its inefficiency in avoiding the civil war. Still, he praises the importance of the conservatives for the new Constitution that meets with Spiess's approval: without their resistance to revolution and to the radicals, the particularist tradition would not have made much impression on modern Switzerland. ${ }^{59}$

Thus, in the second half of our century, Swiss historiography chooses a rather conservative middle way in judging the events of 1847 and $1848^{60}$ and appraising the new Constitution, but far from the liberal enthusiasm of the earlier decades and in a way in the tradition of Jeremias Gotthelf who, once a young liberal, had become a sceptical conservative. ${ }^{61}$ By now, the confessional strife no longer influences an individual's judgement: Hanno Helbling, a Protestant from the Engadin, whose scholarly research had concentrated on medieval (and thus Catholic) Italian thinking before he became the liberal Neue Zürcher Zeitung specialist for the Vatican and later director of its Feuilleton, states in 1963 that 'guilt was uniformly distributed' between the two camps. For Helbling, 1848 is the end of a 'period of searching' followed by the 'responsibility of finding'; what was found should last and yet was open to change, to reform. ${ }^{62}$ Thus the regeneration and Sonderbund issue has definitely become a historical matter, the judgements no longer depend on one's confession 
or political affiliation but rather on one's idea about legitimate ways of change or progress in history. As the Swiss political system has definitely become a search for compromises since the Zauberformel of 1959, a distant and barely involved historian like Georges Andrey in the 1983 History of Switzerland and the Swiss can see the difficult transition from 1798 to 1848 moderated by many compromises which helped to support the revolutionary changes. ${ }^{63}$ Thus, the 1840 s become an important step, but not the only one, within a successful and fairly smooth path to modernisation in politics, society and economics. According to the general shift in postwar historiography, the structural force of the industrial revolution is generally considered more important than the bayonets of Dufour's troops.

In a way surprisingly, it is a historian of economic history who has just recently given another turn to the interpretation of the 1840 s. Hansjörg Siegenthaler has not ignored the fact that the new state made an industrial upturn possible in the second half of the nineteenth century but that uncontested consequence of 1848 may not necessarily be a reason for the people acting in the first half of the century. Based on a 'kulturalistisch aufgerüstete ökonomische Handlungstheorie', an adaptation of the economist's 'rational choice' theory to historical science, Siegenthaler wonders what makes individuals act together with other individuals to promote change, even if it means costs and sacrifices for them. They only do that if they need each other and they need each other if they are in an 'epistemological crisis', if they have lost former certitude. Such a fight for the 'sources of truth' was fought until the decision of 1847 and 1848 brought new 'belief in the rules'. ${ }^{64}$ This interpretation means that the existing economic reasons for a stronger union in Switzerland did not motivate individuals to fight for it. Siegenthaler's position has been further developed by several of his pupils but has also encountered opposition from 'materialistic' historians. ${ }^{65}$ As a result of these recent debates, however, one can say that Siegenthaler's position has convinced most of his fellow historians.

We can briefly sum up this overview of 150 years of historiography as follows:

- the losers of 1847 deploring the broken traditional law;

- the 'idealistic' winners rejoicing about a successful liberal Weltgeist, but moderating their triumphant outbreaks at least from 1891 onwards;
- Grimm's Socialist version of a determined, but materialistically presented progress through a first, bourgeois revolution;

- the 'materialist turn' within liberal historiography since Fueter highlighted the economic aspects of 1848;

- the organic interpretation during the confrontation with the Nazis and Communism, pointing out that the harmonious solution of 1848 accorded with the true nature of the Swiss and was free from foreign influence;

- the neo-conservative shift during the Cold War, sceptical about an age of revolutions;

- finally, an interpretation based on economic theories of rational acting, typical of our times of globalisation and a preponderance of economy in theory and in practice.

Let me finish with some short observations about other recent approaches to 1848 . As the speech of a leading Catholic politician at a commemoration of 1848 shows, the bad feeling on the part of the conservative losers is not as far away as one might think. ${ }^{66}$ This points to the discontinuity, the rupture of the 50 years from 1798 to 1848 which put an end to the Swiss Confederation their ancestors had wanted. Most historians nowadays emphasise that rupture too; if they belong to the left, they often combine their appraisal for the new federal state with the claim already mentioned that the Socialists are its true heirs. ${ }^{67}$ From a feminist point of view, the exclusion of women during the period of nation-building has been interpreted as a result of the influential men's clubs as a basis of the liberal revolution; such political associations provided the shelter of a family without depending on women because new members did not have to be born but were co-opted according to social rules. ${ }^{68}$ Finally, there is a public debate about similarities between the Swiss nationbuilding in the nineteenth century and the further development of institutions within the EU. Surprisingly, there are even prominent authors of the nineteenth century who prophesied a European federal state according to the Swiss model. Thus, the jurist Johann Caspar Bluntschli, a leader of the conservative coup of 1839 in Zurich, stated: 'When one day the ideal of the future (to which Switzerland has shown the way) is realised, then the international Swiss nationality may dissolve into the big European community. It will not have lived in vain nor without glory. ${ }^{69}$ 


\section{Notes}

1. Joachim Remak, A Very Civil War. The Swiss Sonderbund War of 1847 (Boulder/San Francisco/Oxford, 1993).

2. In this survey, which constitutes the first part of this essay, I will only mention the literature when I quote directly. For further information see classic works such as Edgar Bonjour, Die Gründung des schweizerischen Bundesstaates (Basle, 1948) or Erwin Bucher, Die Geschichte des Sonderbundskrieges (Zurich, 1966). Many recent approaches are brought together in the books mentioned in note 3 and in Andreas Ernst et al. (eds), Revolution und Innovation. Die konfliktreiche Entstehung des schweizerischen Bundesstaates von 1848, Die Schweiz 1798-1998: Staat - Gesellschaft - Politik, vol. 1 (Zurich, 1998); Urs Altermatt et al. (eds), Die Konstruktion einer Nation. Nation und Nationalisierung in der Schweiz, 18-20. Jahrhundert, Die Schweiz 1798-1998: Staat - Gesellschaft - Politik, vol. 4 (Zurich, 1998); see also Thomas Christian Müller, 'Die Schweiz 1847-49. Das vorläufige, erfolgreiche Ende der "demokratischen Revolution"?', in: Dieter Dowe et al. (eds), Europa 1848. Revolution und Reform, Forschungsinstitut der Friedrich-Ebert-Stiftung. Reihe Politik- und Gesellschaftsgeschichte, vol. 48 (Bonn, 1998), pp. 283-326. I have described the revolutionary period as it was reflected in the commentaries of the leading liberal newspaper in Vom Sonderbund zum Bundesstaat. Krise und Emeuerung 1798-1848 im Spiegel der NZZ (Zurich, 1998).

3. See Alfred Kölz, Neue schweizerische Verfassungsgeschichte. Ihre Grundlinien vom Ende der Alten Eidgenossenschaft bis 1848 (Berne, 1992), pp. 227-300; Albert Tanner and Thomas Hildbrand (eds), Im Zeichen der Revolution. Der Weg zum schweizerischen Bundesstaat 1798-1848 (Zurich, 1997), especially the contributions of Albert Tanner, "Alles für das Volk". Die liberalen Bewegungen von 1830/31', pp. 51-74 and 'Das Recht auf Revolution. Radikalismus - Antijesuitismus - Nationalismus', pp. 113-37 and Marco Jorio, "Wider den Park mit dem Teufel". Reaktion und Gegenwehr der Konservativen', pp. 139-60.

4. See Neue Zürcher Zeitung, 22 January 1846, entitled 'Über Volkssouveränität' referring to the earlier debate 'ob das Volk der Souverän sei oder ob dieser in dem Rathe der Stellvertreter des Landes gesucht werden müsse' which has now become the question, 'ob das Volk ein unumschränkter, absoluter oder aber ein konstitutioneller Oberherr sein solle'. The editor, Luigi Ercole Daverio, sees it as 'eine Frage über die Schranken der oberherrlichen Gewalt, ob nämlich die Verfassung auch als eine Schranke für den Souverän anzusehen sei oder nicht'. His conclusion is the opposite of Druey's (see note 5), for he says that 'da wo die Stellvertreter eines Volkes unter Ratifikationsverbehalt deselben eine Verfassung erlassen, hat dieselbe eine so bindende Kraft, als irgend ein vertrag, den Einzelne unter sich abgeschlossen und mit Namensunterschriften versehen haben. [...] Die Ansicht dagegen, es sei das Volk ein durchaus selbständiges, unabhängiges Individuum, das nach Belieben Vorsätze fassen, abändern oder unerfüllt lassen kann, müssen wir entschieden verwerfen, als unbegründet in der Theorie und verderblich in der Praxis.'
5. Henri Druey in his Nouvelliste Vaudois, 5 November 1844 , cited by Edgar Bonjour, 'Die Gründung des schweizerischen Bundesstaates' (Basle, 1948), p. 198, says that 'le radicalisme reconnaît au peuple le droit d'exercer sa souveraineté à chaque instant, comme il le veut, sa volonté suprême ne pouvant pas être liée par la constitution qui est un acte de cette volonté et non un contrat.'

6. Tanner, Das Recht auf Revolution (see note 3), p. 122.

7. As quoted in the NZZ, see Maissen, Vom Sonderbund (see note 2), p. 151.

8. Philipp Anton von Segesser to Andreas Heusler (9 February 1848), in Von Segesser/Heusler, Briefwechsel, edited by Victor Conzemius, prepared by Heidi Bossard-Borner, vol. 1 (Zurich/Einsiedeln/Cologne, 1983), p. 494.

9. See Edgar Bonjour, Das Schicksal des Sonderbunds in zeitgenössischer Darstellung (Aarau, 1947); for the contemporary and later authors see also Edgar Bonjour and Richard Feller, Geschichtsschreibung der Schweiz vom spätmittelalter zur Neuzeit, vol. 2 (Basle/Stuttgart, 1979).

10. Constantin Siegwart-Müller, Der Sieg der Gewalt über das Recht in der Schweizerischen Eidgenossenschaft (Altdorf, 1866), pp. v-xi (Vorwort).

11. Joseph Balthasar Ulrich, Der Bürgerkrieg in der Schweiz (Einsiedeln, 1850), pp. iii-vi (Vorrede), 762-8.

12. Bernhard Meyer, Über Annahme oder Verwerfung der neuen Bundesverfassung (Zurich, 1848). See also Bonjour, Gründung (see note 2), p. 182.

13. Jakob Baumgartner, Die Schweiz in ihren Kämpfen und Umgestaltungen von 1830 bis 1850 , vol. 1 (Zurich, 1853), p. vii; vol. 4, pp. 606-7.

14. Jakob Baumgartner, Schweizerspiegel. Drei Jahre unter der Bundesverfassung von 1848 (Zurich, 1851), pp. vii, 235-44; see also Heidi Borner, Zwischen Sonderbund und Kulturkampf. Zur Lage der Besiegten im Bundesstaat von 1848, Luzernische Historische Veröffentlichungen, vol. 11 (Lucerne, 1981), pp. 31-2.

15. Dr C. Weber (i.e. Niklaus Friedrich von Tschudi), Der Sonderbund und seine Auflösung von dem Standpunkte einer nationalen Politik (St Gallen, 1848), pp. 3-7, 36-7; see also Bonjour, Schicksal (see note 9), pp. 66-8.

16. Jakob Amiet, Der siegreiche Kampf der Eidgenossen gegen Jesuitismus und Sonderbund (Solothurn, 1848), cited in Bonjour, Schicksal (see note 9), p. 58

17. J. Martin Rudolf, Die Geschichte der Ereignisse in der Schweiz seit der Aargauische Klosteraufhebung 1841 bis zur Auflösung des Sonderbundes und zur Ausweisung der Jesuiten (Zurich, 1848), pp. 489-95; see also Bonjour, Schicksal (see note 9), pp. 65-6.

18. See for example the woodcut Alt und Jung by Jakob Ziegler with Jacob Amiet's text, in Illustrieter Schweizer Kalender (Ziegler-Kalender, 1850), p. 17. Similarly the Neue Zürcher Zeitung celebrating the new Constitution on 14 September 1848 states that

über Berge und Thäler haben sich heute die Eidgenossen ihren Jubel zugedonnert; die wenigen, die in finsteres Schweigen sich hüllen, sollen unsere Freude nicht trüben. Keine Freudenfeuer dürfen heute von den Bergeshöhen herableuchten, von welchen die ersten Feuersignale der schweizerischen Freiheit erglänzten. Wohlan! die Reihe ist jetzt an den jüngern Söhnen der Freiheit. An diesen ist es nun, ihren ältern Brüdern 
die im Laufe der Jahrhunderte durch herrschsüchtige Magnaten und freiheitsfeindliche Priester ihnen verkümmerte Freiheit zu verkünden - und zu bringen. Von dem geistigen Drucke der neuen Gessler die Urstätte schweizerischer Freiheit zu befreien, wird nicht das letzte Bestreben der den neuen Bund freudig begrüssenden Eidgenossen sein.

19. For the denigration of the 'oligarchic' ancien régime see Andreas Würgler, Die Legitimierung der Revolution aus den Unruhen des Ancien Régime durch die schweizerische Nationalhistoriographie des 19. Jahrhunderts, in Ernst et al. (eds), Revolution und Innovation (see note 2), pp. 79-90.

20. For Tillier see Bonjour, Schicksal (see note 9), p. 72.

21. Guillaume-Henri Dufour, Campagne du Sonderbund et événements de 1856. Précédé d'une notice biographique d'Edouard Sayous (Neuchâtel/Geneva/ Paris, 1876); see also Olivier Reverdin, La guerre du Sonderbund vue par le Général Dufour, Juin 1847-Avril 1848. D'après des lettres et des documents inédits (Geneva, 1948; reprinted 1997). Early historiographic praise of Dufour is found in Eusèbe-Henri Gaullieurs, La Suisse en 1847 (Geneva, 1948); see Bonjour, Schicksal (see note 9), p. 69.

22. Peter Feddersen, Geschichte der Schweizerischen Regeneration von 1840 bis 1848 (Zurich, 1867), pp. iii-v, 567, 582.

23. Karl Dändliker, Geschichte der Schweiz (Zurich, 1887), pp. 615, 654.

24. Johanes Dierauer, Geschichte der Schweizerischen Eidgenossenschaft, vol. 5 (Gotha, 1917), pp. 679, 686, 785-6.

25. Numa Droz, 'Die Wiedergeburt', in Paul Seippel (ed.), Die Schweiz im neunzehnten Jahrhundert, vol. 1 (Berne/Lausanne, 1899), pp. 275-6 where he says that 'die gemässigten Elemente, welche allein aufzubauen vermögen, hatten die Oberhand gewonnen. [...] Jetzt war das Werk der Wiedergeburt vollbracht. Die fremde Vormundschaft war gebrochen. Die Schweiz trat in eine neue Ära ihrer Geschichte ein'.

26. Theodor Curti, Geschichte der Schweiz im 19. Jahrhundert (Neuchâtel, 1901), p. 539.

27. Max Huber, Der schweizerische Staatsgedanke (Zurich, 1916), p. 13.

28. Nabholz, Hundertiahrfeier (see note 51), (referring to Huber); Ulrich Im Hof, Vom Bundesbrief zur Bundesverfassung (Rorschach, 1948), p. 164; Wolfgang von Wartburg, Geschichte der Schweiz (Munich, 1951), p. 205.

29. Joseph Hürbin, Handbuch der Schweizer Geschichte, vol. 2 (Stans, 1903), pp. 605-11.

30. Georg Kreis, Der Mythos von 1291. Zur Entstehung des schweizerischen Nationalfeiertags (Basle, 1991).

31. See also François de Capitani, 'Die Suche nach dem gemeinsamen Nenner - der Beitrag der Geschichtsschreiber', in François de Capitani and Georg Germann, Auf dem Weg zu einer schweizerischen Identität 1848-1914. Probleme - Errungenschaften - Misserfolge (Fribourg, 1987), pp. 25-35.

32. Georg Kreis, 'Das Verfassungsjubiläum von 1948 ', in Jubiläen der Schweizer Geschichte 1798-1848-1998, Studien und Quellen, vol. 24 (Berne, 1998), pp. 133-5.
33. Carl Hilty, Die Bundesverfassungen der Schweizerischen Eidgenossenschaft (Berne, 1891), pp. 402-7.

34. Eduard His, Geschichte des neuern Schweizerischen Staatsrechts, vol. 2 (Basle, 1929), pp. 773-4; vol. 3 (Basle, 1938).

35. Andreas Heusler, Schweizerische Verfassungsgeschichte (Basle, 1920), pp. $375-81$.

36. Ernst Gagliardi, Geschichte der Schweiz von den Anfängen bis zur Gegenwart, first edition, vol. 2 (Zurich, 1920), pp. 426, 434. On p. 435 Gagliard names the three historical sources of the new Constitution as 'alemannisches Streben nach Bewahrung der Volksfreiheit', 'Rousseausche Lehre von der Volkssouveränität' and 'das Beispiel Nordamerikanischer Union'.

37. Ernst Gagliardi, Geschichte der Schweiz von den Anfängen bis zur Gegenwart, 4 th edition, vol. 3 (Zurich, 1939), pp. 1378-81 where he writes that 'Ökonomische Zwangsläufigkeit spielte beim Kampf um das neue Grundgesetz sonach eine entscheidende Rolle.' See also p. 1415.

38. See for example the third volume of Seippel's Swiss history (see note 25) which contains chapters on agriculture, industry, transport and the working-class movement.

39. William E. Rappard, Le facteur économique dans l'avènement de la démocratie moderne en Suisse, vol. 1, L'agriculture à la fin de l'Ancien Régime (Geneva, 1912). No further volumes published.

40. Eduard Fueter, Die Schweiz seit 1848. Geschichte, Politik, Wirtschaft (Zurich/ Leipzig, 1928), pp. 12-19, 39-43. Emil Dürr, Neuzeitliche Wandlungen in der schweizerischen Politik. Historisch-politische Betrachtung über die Verwirtschaftlichung der politischen Motive und Parteien (Basle, 1928), is another testimony to this new interest among historians for economic change, but as far as 1848 is concerned he accords more importance to politics than to economy (p. 22).

41. Hans Nabholz, 'Die Entstehung des Bundesstaates wirtschaftsgeschichtlich betrachtet', in Mélanges offerts à Charles Gilliard (Lausanne, 1944) pp. 574-90. See also Nabholz's obituary notice on Fueter in Neue Zürcher Zeitung, 2 December 1928, and Hans Conrad Peyer, 'Der Historiker Eduard Fueter. Leben und Werk', in 145. Neujahrsblatt zum Besten des Waisenhauses Zürich für 1982, pp. 5-72, especially pp. 53 and 57.

42. Walther Rupli, Zollreform und Bundesreform in der Schweiz 1815-1848. Die Bemühungen um die wirtschaftliche Einigung der Schweiz und ihr Einfluss auf die Gründung des Bundesstaates von 1848 (Zurich, 1959), pp. 206-7. See also Jean-Francois Bergier, Die Wirtschaftsgeschichte der Schweiz (Zurich, 1959), pp. 206-7. See also Jean-François Bergier, Die Wirtschaftsgeschichte der Schweiz (Zurich, 1983), p. 210 where he comments that 'die Industrialisierung hat, wenn auch spät, vermutlich mehr als jeder andere Faktor zur Einführung eines solchen [politischen, sozialen und institutionellen] Apparates beigetragen'.

43. See for example Karl Schib, Illustrierte Schweizergeschichte für jedermann (Zurich, 1944), pp. 179-81 and 'Vom Staatenbund zum Bundesstaat', in Schweizerische Demokratie (see note 49), pp. 26-7. See also Walter 
Stampfli, 'Die Bundesverfassung von 1848 und die schweizerische Wirtschaft', in Schweizerische Demokratie, pp. 331-5.

44. Werner Näf, Die Schweiz in Europa. Die Entwicklung des schweizerischen Staates im Rahmen der europäischen Geschichte (Berne, 1938), pp. 57-8.

45. Gottfried Guggenbühl, Geschichte der Schweizerischen Eidgenossenschaft, vol. 2 (Erlenbach, 1948); see pp. 416-20, which cover the 'home-grown will' (einheimischer Wille) that in one of the 'luckiest' years of Swiss history, made possible the new Constitution, which included a 'considerable swissification' (Verschweizening) of the American model.

46. Edgar Bonjour, Geschichte der Schweiz im 19. und 20. Jahrhundert, Geschichte der Schweiz, edited by Hans Nabholz et al., vol. 2 (Zurich, 1938), pp. 433-62.

47. Bonjour, Gründung (see note 2), pp. 5-6.

48. Bonjour, Schicksal (see note 9), p. 73 and Gründung (see note 2), p. 152. For Basle see Bonjour, Basels Vermittlung in den Sonderbundswirren (Basle, 1948) which originally appeared in Archiv des Historischen Vereins des Kantons Berm, vol. 39 (Berne, 1948).

49. Schweizerische Demokratie 1848-1948. Ein Jubiläumswerk, edited by Arnold H. Schwengeler (Murten, 1948), pp. 13-16, 35. On p. 34 Abderhalden's explanation of the importance of the new Constitution is very like Celio's. He declares: 'sie überwand die im Sonderbundskrieg zum Ausdruck gekommenen Gegensätze und schuf als Abschluss und Krönung einer jahrhundertlangen Entwicklung aus einem schwerfälligen Bund selbständiger Staaten einen allen Anforderungen der Neuzeit gewachsenen Bundesstaat'.

50. Alphons Iten, President of the Swiss Ständerat, as cited in Kreis, Verfassungsjubiläum (see note 32 ), p. 160 . Kreis discusses the official jubilees and the differences between the commemorative discourses of the different political parties.

51. Hans Nabholz, 'Zur Hundertjahrfeier der Bundesverfassung des Jahres $1848^{\prime}$, in Die Schweiz. Ein nationales Jahrbuch 19 (1948), pp. 3-16, especially pp. $3,8,11,13$.

52. Max, Huber, Die Bundesverfassung von 1848 als Ausdruck schweizerischen Freiheitswillens, Kantonal-Zürcherische Hundertjahrfeier der Bundesverfassung, 4 Juli 1948 (Zurich, 1948), pp. 14-25.

53. William E. Rappard, Die Bundesverfassung der Schweizerischen Eidgenossenschaft 1848-1948 (Zurich, 1948), pp. 429-33

54. Karl Schmid, 'Ein Jahrhundert Bundesstaat', in Schmid, Zeitspuren. Aufsätze und Reden, vol. 2 (Zurich/Stuttgart, 1967), pp. 32-41.

55. See details about the quarrel concerning an exhibition commemorating 1848 in Kreis, Verfassungsjubiläum (see note 32), pp. 164-7, and also pp. 148-50 for comment on the attempt by the Socialists to lay claim to the heritage of 1848 .

56. Robert Grimm, Geschichte der Schweiz in ihren Klassenkämpfen (Berne, 1920), pp. 368-82, 405-7.

57. Peter Bichsel, Des Schweizers Schweiz (Frankfurt am Main, 1997), pp. 16-17 (first printed in 1969).
58. Max Frisch, Stiller, in Gesammelte Werke in zeitlicher Folge, vol. 3 (Frankfurt am Main, 1976), p. 596 and achtung: Die Schweiz, in Gesammelte Werke, p. 336. See also the recent thesis by Sonja Rüegg, 'Ich hasse nicht die Schweiz, sondern die Verlogenheit'. Das Schweiz-Bild in Max Frischs Werken 'Graf Öderland', 'Stiller' und 'achtung: die Schweiz' und ihre zeitgenössische Kritik (Zurich, 1998), especially pp. 241, 312-14 and 389 (referring to a letter written in 1991) where the author remarks:

Der Rekurs auf die Staatsgründer von 1848 zieht sich von Stiller über achtung: Die Schweiz durch bis zu dieser letzten öffentlichen Äusserung Frischs. [...] Mit der Berufung auf die Gründer von 1848 erinnert Frisch das heutige Bürgertum, das sich als Nachkomme der liberalen Gründerväter versteht, immer wieder [...] an ihr eigenes, ursprüngliches Versprechen und ihr Versagen davor.

59. Emil Spiess, Das Werden des Bundesstaates und seine Entwicklung um modernen Europa, Illustrierte Geschichte der Schweiz, vol. 3 (Einsiedeln/ Zurich/Cologne, 1961), pp. 155-7, 167-8, 184.

60. See also Peter Dürrenmatt, Schweizer Geschichte, vol. 2 (Zurich, 1976), pp. 641-78.

61. For Gotthelf see Albert Tanner, "Vom "ächten Liberalen" zum "militanten" Konservativen. Jeremias Gotthelf im politischen Umfeld seiner Zeit', in Hanns Peter Holl and J. Harald Wäber, 'Zu schreien in die Zeit hinein.' Beiträge zu Jeremias Gotthelf/Albert Bitzius (1797-1854) (Berne, 1997), pp. 11-59.

62. Hanno Helbling, Schweizer Geschichte (Zurich, 1963), pp. 130, 134.

63. George Andrey, 'Auf der Suche nach dem neuen Staat (1798-1848), in Geschichte der Schweiz und der Schweizer (Basle/Frankfurt am Main, 1986), p. 630. Ernst Bohnenblust, Geschichte der Schweiz (Erlenbach, 1974), p. 439 also calls the new Constitution a 'work of agreement, a compromise between the parties'. A similar scientific distance marks the contributions of Jean-Charles Biaudet and Erwin Bucher in Handbuch der Schweizer Geschichte, vol. 2 (Zurich, 1977), and Ulrich Im Hof, Geschichte der Schweiz (Stuttgart, 1974), pp. 106-9.

64. Hansjörg Siegenthaler, 'Supranationalität, Nationalismus und regionale Autonomie. Erfahrungen des schweizerischen Bundesstaates, Perspektiven der europäischen Gemeinschaft,' in Traverse, 3 (1994), pp. 117-40; see also Siegenthaler, 'Weg der Vernunft in die Modernität. Vom Kampf um die Quellen der Wahrheit zur Gründung des Bundesstaates', Neue Zürcher Zeitung, 27/28 June 1998, p. 71.

65. See in Ernst et al. (eds), Revolution und Innovation (see note 2), the contributions of Patrick Halbeisen and Margrit Müller, Christoph Guggenbühl and Thomas Christian Müller who defend one side of the question and of Hans Ulrich Jost and Cédric Humair who disagree.

66. Carlo Schmid (Landammann of Appenzell-Innerrhoden), 'Geschichte der Integration', in Republikanisches Bankett der Neuen Zürcher Zeitung zum 150-Jahr-Jubiläum des Schweizerischen Bundesstaates. 26 Juni 1998. Die Reden im Wortlaut (Zurich, 1998), pp. 9-10. 
67. For example Josef Lang, who also contributed an article about the Catholic radicals to Ernst, Revolution (see note 2), pp. 259-70; see his statements in MOMA, Monatsmagazin für neue Politik, 12.97/1.98. See also Tobias Kästli, Die Schweiz - eine Republik in Europa. Geschichte des Nationalstaats seit 1798 (Zurich, 1998).

68. Lynn Blattmann and Irène Meier (eds), Männerbund und Bundesstaat. Uber die politische Kultur der Schweiz (Zurich, 1998).

69. Cited in Daniel Thürer, 'Die drei Paradoxe in der Verfassung von 1848. Über ihre Relevanz im Zeitalter der Globalisierung, NZZ, 27/28 June 1998, p. 69. 